\title{
Abortion is the same as Slavery
}

\author{
*Samuel A Nigro \\ Case Western Reserve University School of Medicine, USA
}

Submission: July 15, 2017; Published: July 26, 2017

*Corresponding author: Samuel A Nigro, Retired, formerly of Case Western Reserve University School of Medicine, USA, Tel: 2169320575;

Email: sam@docnigro.com

\section{Short Communication}

Every culture has its contagious evils allowed by law and accepted by citizens as the common good. Once, every country had slavery; some countries mistreated women; some countries had communism and deprived all of personal property; some killed Jews or dehumanized others; in America, anti-Catholicism has always been accepted and anti-religions is growing. Every country has its contagious evil accepted as a good. Today, abortion has replaced slavery human DNA creatures, at a stage of life every human being had to go through, are property belonging to others; without rights; deprived of personal development and independence; without the right to choose for oneself; declared "non-persons" by law; deprived of life, liberty and pursuit of happiness; not allowed "created equal;" without descendants; promoted as a "necessary good" when exploited, dehumanized and misused by others including scientists; and inhumanly proclaimed "good" whenever destroyed. Abortion has replaced slavery they made it invisible. You would not have wanted to be a slave or aborted.

Abortion is more like Islamic slavery with everybody dead, while slavery in the Americas became the irony of ironies: Negros in the Americas with slave ancestors are the luckiest people in the world because, if anywhere else, they would be likely dead or destitute or trying to immigrate to the Americas. After living three years in many parts of Africa, Keith Richburg, when a correspondent for the Washington Post, in 1997, wrote a book, Out of America, A Black Man Confronts Africa. He wrote "Thank God my ancestor got out, because I am not one of them... In short, thank God that I am an American" (He was actually thanking "slavery"). And James Baldwin wrote, "The Negro has been formed by this nation (America), for better or for worse, and does not belong to any other--not to Africa and certainly not to Islam." As Representative Louis Stokes would say that he had been in every other country long enough to know that being born in America was to win the lottery if you worked to take advantage of what was available. He meant what Dr. Martin Luther King used to determine humanity: "the content of one's character," echoed by Supreme Court Justice thurgood Marshall as "the quality of intent." Humanbeingness is more than the quantity of melanin in one's skin. In time, those for abortion will be condemned as are those who were for slavery--human DNA creatures are being dehumanized. Not human? Slavery because of color....abortion because of size... just more of "the huddled masses yearning to be free..."

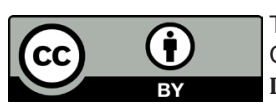

This work is licensed under Creative Commons Attribution 4.0 License DOI: 10.19080/PBSIJ.2017.5.555654

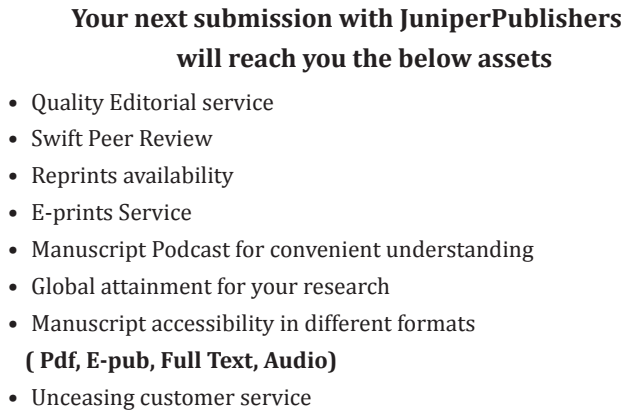

Track the below URL for one-step submission https://juniperpublishers.com/online-submission.php 